\title{
Teaching Materials Development Using Kvisoft Flipbook Maker Application in Creative Economy Courses with 4-D Model Design
}

\author{
P K D Lubis $^{1}$, D Adriani ${ }^{2}$ and A I Silitonga ${ }^{3}$ \\ ${ }^{1,2}$ Economic Education Study Program, Faculty of Economics, Universitas Negeri Medan, Indonesia \\ ${ }^{3}$ Digital Business Study Program, Faculty of Economics, Universitas Negeri Medan, Indonesia \\ Email: putrikemala@unimed.ac.id,deni_adriani@unimed.ac.id,agnesirenesilitonga@unimed.ac.id
}

\begin{abstract}
This study aims to increase student independence in learning Creative Economy using e-module learning media with the Kvisoft Flipbook Maker application. The research method uses R\&D (Research and Development) with a 4-D development model from Thiagarajan namely Define, Design, Develop, \& Disseminate, referring to four stages, namely: the define stage to define problems in learning. The design stage is to produce the initial product design and research instrument. Development stage to obtain product and instrument feasibility. The disseminate stage is for experimentation in e-module usage classes with the Kvisoft Flipbook Maker application. The research instrument was a material expert validation sheet, linguist validation, media expert validation, and response questionnaires for students. The research subjects are students of the fifth semester of the Economic Education Study Program for the 2021/2022 academic year who are taking creative economics lectures. The validation assessment by material experts obtained a percentage of $84 \%$ with very appropriate interpretations, linguists $78 \%$ with proper interpretations and media experts obtained a percentage of $90 \%$ with very appropriate interpretations. The average score of the overall assessment is $84 \%$ with a very decent interpretation. The results of the study are expected to use e-modules with the Kvisoft Flipbook maker application in Creative Economy learning to have a positive impact on improving student learning outcomes and creativity.
\end{abstract}

Keywords: Kvisoft flipbook, Application, 4-D model.

\section{INTRODUCTION}

The government's call to stay at home and study from home has changed the face of the learning process, which has been taking place face-to-face, to take place online. The world of education must make adjustments to this situation. Ahead of the establishment of the New Normal in June 2020, there is a discourse from the government not to postpone the new school year. This makes the community nervous, especially people where the area where he is located is still classified as a red zone in the spread of COVID-19. Aspects of education underwent drastic changes with the development of the industrial revolution. The use of educational technology in the industrial revolution can solve existing educational problems. The use of technology in learning can overcome problems that arise during the Covid-19 pandemic. Teachers can teach anywhere and from anywhere.
The use of technology in education has long been applied, even since the use of the Competency-Based Curriculum (KBK) in 2006. However, the existence of technology in learning is only a medium or learning aid. Technology is not directly integrated in the implementation of learning and is only used in some teaching materials. The application of technology in education is one of the important points in the development of the Industrial Revolution 4.0 which is called Education 4.0 (Education 4.0) and the 2013 Curriculum as a guide for implementing education in Indonesia.

The existence of technology has become increasingly important in learning since the industrial revolution 4.0 era and the 2013 Curriculum was applied in the learning process. Lecturers can develop digitalbased teaching materials that can be used by students anywhere and anytime. It is intended that the learning process does not only stop on campus but can continue 
outside the campus. Teaching materials are also more developed in accordance with the demands of industry and today's technological advances in order to broaden the student learning experience.

Online learning lecturers need to modify and develop teaching materials so that students do not experience difficulties in understanding the subject matter. Tools to convey messages and make it easier to learn something can use learning media. Learning media has a very important role in the learning process can make the learning atmosphere more interesting and meaningful [1]. Electronic teaching materials are also a form of lecturer self-development in the face of $21 \mathrm{st}-$ century learning and the Industrial Revolution 4.0. Creative and innovative lecturers can make learning tools in digital format. Electronic teaching materials are in principle similar to manual teaching materials that describe basic competencies (KD), Competency Achievement Indicators (GPA), and practice questions [2].

The development of the times and increasingly widespread technology and changes in the learning process require learning media to experience a broader process of innovation. The development of science and technology increasingly encourages the creation of interactive learning media. Technology and computerbased learning media began to emerge. E-learning is used during the learning process. In addition to Elearning, digital modules are teaching media that emerged from the development of science and technology. The e-module has the same function as the print module. Print modules and electronic modules make it easier for readers to master the learning material [3].

The kvisoft flipbook maker application is an application that supports as a learning medium that will assist in the learning process because this application is not only focused on writing but can include motion animation, video, and audio that can make an interesting interactive learning media so that learning is not monotonous. E-modules using the kvisoft flipbook maker application can be accessed offline and do not have to spend a lot of money because they are in the form of soft files [4].

The creative economy or creative industry is an industry originating from the use of individual creativity, skills, and talents to create prosperity and employment by generating and exploiting creative and creative power as a collection of economic activities related to the creation or use of knowledge and information [5]. Starting in 2018, the creative economy course has been established as a course in the Universitas Negeri Medan Economic Education study program. Learning creative economy courses is a concept of a new economic era that requires creativity so that students are able to give birth to ideas and ideas where students are able to become part of entrepreneurs who can manage their business. The development of e- module teaching materials using the kvisoft flipbook maker application is expected to build student motivation in studying creative economy courses so that an attitude of curiosity, critical thinking, creative action, innovation, results in inventions that can be directly useful in life [6].

Lecturers as facilitators in the learning process must be able to provide changes so that the objectives of the lecture can be achieved properly. One of the efforts that can be done is to develop teaching materials that are in accordance with the current situation and conditions. Through the development of creative economy emodule teaching materials, it is hoped that people who have: 1) intrinsic motivation, 2) curiosity, 3) critical thinking, 4) act creatively, and innovate, resulting in discoveries (invention) that can be used directly in life.

\section{LITERATURE REVIEW}

Teaching materials can be interpreted as all forms of materials that are arranged systematically that allow students to learn by being designed according to the applicable curriculum. Teaching materials are a set of learning tools or tools that contain learning materials, methods, limitations, and ways of evaluating which are designed systematically and attractively in achieving the expected goals, achieving competencies, or subcompetencies with all their complexity. The teaching materials used by the lecturers, in this case, are to create an atmosphere of teaching and learning that goes well and is conducive in accordance with step two of the directives contained in the teaching materials themselves. Thus, this is very important for all lecturers to do not only as a reference but also as a tool and tool in the achievement of the KBM process on an ongoing basis. With teaching materials, lecturers will be more consistent in delivering material to students [5].

The development of teaching materials is a form of developing learning strategies that are in accordance with certain principles adapted from learning theories. Meanwhile, if further elaborated, it is explained that the development of teaching materials is not only based on the interests of the developer but is an alternative solution to learning problems. Students, not only interact with lecturers but can also interact with learning resources used to achieve the desired results.

Creativity is found in all societies and countries, rich or poor, large or small, developed or developing. The word "creativity" is associated with originality, imagination, inspiration, ingenuity, and inventiveness. This is the inner characteristic of the individual imaginative and expressive ideas, related to knowledge, ideas are the essence of intellectual capital. Creative industries can be defined in a broad sense as follows: a. A cycle of creation, production, and distribution of goods and services that uses creativity and intellectual capital as the main inputs. b. A set of knowledge-based activities, focused but not limited to the arts, has the 
potential to generate revenue from trade and intellectual property rights. c. Tangible products and intangible intellectual or artistic services with creative content, economic value, and market objectives [5].

Kvisoft Flipbook Maker is a powerful software designed to convert PDF files to digital publication turning pages or digital books. This software can change the appearance of PDF files to be more attractive like a book. In addition, Kvisoft Flipbook Maker can also create PDF files such as magazines, digital magazines, flipbooks, company catalogs, digital catalogs, and others. Kvisoft Flipbook Maker can add image files, pdf, swf, and video files in FLV and MP4 formats. While the output of this software can be in the form of HTML, EXE, ZIP, and APP. The TI Flash output flips the book as an HTML format that allows it to be uploaded to a website for online viewing. Outputs as a stand-alone EXE for CD delivery. Package it as a ZIP format for a quick email. And the output in the form of an APP can be used on iphone, Tablet, ipad. The use of the kvisoft flipbook maker application produces digital format books that make it easy for readers to access wherever and whenever they want because this digital book can be accessed via smartphones. This kvisoft flipbook maker application makes it easy for users to enter/insert multimedia facilities, such as text, images, animations, music into digital books, so that students do not feel bored/bored when reading the digital book [7].

\section{RESEARCH METHODS}

This study uses Research and Development (R\&D) research methods with a $4 \mathrm{D}$ development model (Four D Model). This research is intended to develop interesting learning media to foster motivation and learning outcomes for students of Economics Education study program. The teaching materials developed are in the form of electronic modules (e-modules) using the Kvisoft Flipbook Maker application in the creative economy course. The research design uses the $4 \mathrm{D}$ model (four-D) proposed by Thiagarajan, Semmel, and Semmel [2]. This development model consists of 4 stages, namely defining, designing, developing, and disseminating.

The research subjects are students of the Economic Education study program who are registered in the fifth semester of the 2021/2022 academic year who are taking creative economics courses.

The types of data used are qualitative and quantitative data. Qualitative data was obtained by means of interviews, observations, as well as criticism, and suggestions from the validator. Interviews were conducted after the last cycle was carried out. Some students were asked questions referring to the interview guide. Quantitative data was obtained through the assessment of the validators using a validation sheet and then analyzed using percentages.
The data analysis technique used in this study is a qualitative descriptive analysis technique that describes the results of product development in the form of emodule teaching materials using the kvisoft flipbook maker application. The data collection tool used is in the form of a validation sheet given to the expert. A validation sheet is given to the expert in the form of a Likert scale.

Table 1. Category validation value

\begin{tabular}{cc}
\hline Answer category & Statement score \\
\hline Very good & 5 \\
Well & 4 \\
Enough & 3 \\
Not good & 2 \\
Very good & 1 \\
\hline
\end{tabular}

Data analysis is used to analyze the data that has been obtained from the assessment of the validators. The data is then analyzed using the following calculations:

Percentage $=\underline{\text { Total score obtained }} \times 100 \%$ Highest score

The results of the percentage of eligibility that have been obtained are then interpreted using the eligibility score interpretation criteria which can be seen in the following table:

Table 2. Validation score interpretation criteria

\begin{tabular}{cc}
\hline Evaluation & Interpretation Criteria \\
\hline $0 \%-20 \%$ & Very unworthy \\
$21 \%-40 \%$ & Not worth it \\
$41 \%-60 \%$ & Decent enough \\
$61 \%-80 \%$ & Worthy \\
$81 \%-100 \%$ & Very worth it \\
\hline
\end{tabular}

\section{RESULT AND DISCUSSION}

\subsection{Analysis Stage}

Students need teaching materials in the form of emodules because during the COVID-19 pandemic, students' study online and there are limited reference books for Creative Economy courses. The development of teaching materials using the Kvisoft Flipbook Maker application can help students learn independently and is expected to improve learning outcomes.

\subsection{E-module Development Process with Flipbook Maker}

Prior to the development of e-modules, in learning the Creative Economy course, students received material from the explanation from the lecturer in the form of PowerPoint media and other reference books. The availability of Creative Economy books and other reference sources is very limited, so it is necessary to develop e-modules so that students have independent learning media. The development of this E-module 
using the kvisoft flipbook maker application is useful for modifying PDF files to pages in the form of digital publications. E-module development uses a 4-D development model to the disseminate stage.

\subsection{Stage of Design}

The design phase consists of designing the developed product, designing the product content, and making research instruments. The first step is to design an outline of the contents of the e-module. The initial part of the e-module contains, front cover, subtitle cover. The contents section contains; material descriptions, learning activities, summaries, assignments, answer keys. The cover contains, evaluation, answer key, glossary, bibliography, cover, and back cover. After the design has been arranged, the researcher designs it in the kvisoft flipbook maker application. After the design was completed, the researcher created an instrument for validation by material, language, and media experts.

\subsection{Development Phase (Development)}

The stage for selecting and determining the content design and presentation of the e-module. The e-module that has been designed and in the form of prototype 1 will be reviewed by linguistic, material, and graphic experts in the form of suggestions and input for the feasibility of the e-module. After the researchers improved the e-module according to the input of the experts. Furthermore, it was validated to determine the feasibility of the e-module using the kvisoft flipbook maker application before being tested, limited to students of the Economic Education study program. The validation results will be analyzed in the form of a percentage so that the feasibility of the e-module using the kvisoft flipbook maker application based on a scientific approach can be known.

\subsection{E-module Eligibility with Flipbook Maker}

The feasibility of the E-module was obtained from the results of the validation and trial results. The feasibility includes the feasibility of the content of the material, language, and graphics. The feasibility of this E-module is known from the validation of experts.

Table 3. Recapitulation of Validation Results

\begin{tabular}{cccc}
\hline No & Expert & Percentage & Information \\
\hline 1. & Material & $84 \%$ & Very worth it \\
2. & Language & $78 \%$ & Worthy \\
3. & Media & $90 \%$ & Very worth it \\
& Overall Average & $84 \%$ & Very worth it \\
\cline { 2 - 4 } & Score & & \\
\cline { 2 - 4 } & & Source: Processed by researchers, 2021.
\end{tabular}

Based on table 3, the average score of the material validator assessment is $84 \%$ with very decent criteria.
There are several indicators in the assessment, namely indicators of the feasibility of content quality \& objectives, instructional quality, technical quality. The average score of the material validation results is $84 \%$ in the very feasible category. This e-module media is presented with several tools that support the learning process, such as illustrations, videos, and some questions that can be used to deepen the material. This is in accordance with the research of Widyaningrum [3] which says that the picture can clarify student understanding \& help students remember the material being studied. The feasibility of language was measured using the indicators of the feasibility of the quality of the content $\&$ purpose, the overall result was $78 \%$ in the appropriate category. Grammar is also adjusted according to KBBI rules.

In the assessment of the media using indicators of the quality of content \& objectives, as well as technical quality, in order to obtain an overall score of media validation, which is $90 \%$, the category is very feasible. The presentation of the appearance of the e-module is made as attractive as possible with a harmonious layout, font color, image illustration, \& background to make it easier for students to access it. Interactive learning media help teach material that is considered abstract so that it makes things come alive. The evaluation by the material, language, and media validators obtained an average percentage of $84 \%$, meaning that the media was declared very feasible. Based on the validation obtained, the developed learning media can be continued in the trial.

\section{CONCLUSION}

E-module development using the kvisoft flipbook maker application in the Creative Economy course uses a 4-D development model, carried out until the Develop stage. After being assessed by the validator on the emodule, the validation results were obtained by material experts with $84 \%$ of very feasible criteria, linguists with $78 \%$ of eligible criteria, and media experts with $90 \%$ of very feasible criteria. From the results of the validation of material, language, and media experts, the average eligibility of $84 \%$ was very feasible. So, it is stated that the e-module is very well applied as a learning medium.

\section{SUGGESTION}

The development of e-modules using the kvisoft flipbook maker application can be used for lecturers to enrich teaching materials used in class and train creative thinking skills. Lecturers can apply e-modules that have been developed to overcome difficulties in delivering solid material so that students can learn independently. It should be carried out on trials on a wider scale and further research to determine the learning outcomes of using this e-module in learning. For further research to complete the stages in the development of ADDIE, namely the evaluation stage. 


\section{REFERENCES}

[1] Anum A, Pengembangan Media Pembelajaran Berbasis Video Pada Pembelajaran Daring Di Masa Pandemi 2020 pp 87-94

[2] Yulaika N F, Harti H and Sakti N C, Pengembangan bahan ajar elektronik berbasis flip book untuk meningkatkan hasil belajar peserta didik J. Pendidik. Ekon. Manaj. dan Keuang. $2020.467-76$

[3] Widyaningrum $P$ and Patrikha F D, Pengembangan E-Modul Dengan Flipbook Maker Kd 3.6 Menganalisis Perilaku Konsumen Dalam Bisnis Ritel Kelas XI BDP di SMK Negeri 2 Tuban Tata Niaga , 2020. 9 1048-1054

[4] Wibowo E and Pratiwi D D, Pengembangan Bahan Ajar Menggunakan Aplikasi Kvisoft Flipbook Maker Materi Himpunan Desimal J. Mat. 2018. 1 147

[5] Rosidhah E and Forijati R, Pengembangan bahan ajar kewirausahaan berbasis ekonomi kreatif Semin. Nas. Manajemen, Ekon. dan Akunt. (Kediri: Economic and Business Faculty) pp 2020. 241-251

[6] Sumardiningsih S, Mulyani E and Marzuki, Model Pendidikan Ekonomi Kreatif Berbasis Karakter Sebagai Bridging Course Pembelajaran Mata Kuliah Kewirausahaan J. Kependidikan. 2013. 43 69-77

[7] Divayana D G H, Suyasa P W A and Adiarta A, Pelatihan Pembuatan Buku Digital Berbasis Kvisoft Flipbook Maker Bagi Para Guru di SMK Ti Udayana Abdimas Dewantara. 2018. 1 31-44 